\title{
Accumulation by dispossession and green grabbing: wind farms, lease agreements, land appropriation in the Brazilian semiarid
}

\author{
Mariana Traldi
}

${ }^{\text {I }}$ Federal Institute of Education, Science and Technology of São Paulo, Hortolândia, SP, Brazil.

\begin{abstract}
Wind power presents itself as an alternative to fossil fuels, playing an important role in fighting climate change. In that context, the Brazilian semiarid inland emerges as a new frontier for the wind industry given its high potential. Since being the landowner also means being the wind owner, we sought to understand how the processes of wind and land appropriation to produce wind power occur in the light of two concepts, 'accumulation by dispossession' and 'green grabbing'. To that end, fourteen wind lease agreements were analyzed. It was concluded that: the wind lease contracts are the legal instrument that enables the appropriation of wind and land; that the appropriation of the wind is a process of 'accumulation by dispossession, in which there is the privatization of a common good; and that this process only happens because of the land appropriation, understood as being a green grabbing process.
\end{abstract}

Keywords: Wind power; Brazilian semiarid inland; accumulation by dispossession and green grabbing.

São Paulo. Vol. 24, 2021

Featured Topic:

Decolonial Insurgences and Emancipatory Horizons: Contributions of Political Ecology

DOI: http://dx.doi.org/10.1590/1809-4422asoc20200052r2vu2021L4TD 


\section{Introduction}

While the use of wind as a source for producing electricity dates back to the $19^{\text {th }}$ century its commercial use only became consolidated at the end of the $20^{\text {th }}$ century and beginning of the $21^{\text {st }}$. That was due to the high costs involved in producing it and its low efficiency compared to systems based on fossil fuels. It was only the combination of increasing energy demand worldwide and the threatened finitude of fossil fuels, two crude oil supply shocks ${ }^{1}$ and the institutionalization of the environmental problems associated to climate change, that the technological development to produce wind power was restarted and its commercial use became feasible (DUTRA, 2001).

That movement, initiated in the 1980s, was headed by European countries like Denmark and Germany and by the United States. By the Years 2000, a considerable number of western European countries were already using wind power to some extent and had programs in place to amplify the installation of wind farms, supported by their governments.

Since then wind power capacity worldwide has been growing and expanding geographically. Two related events explain that territorial expansion; the reduction in the availability of onshore areas with wind power potential in the central countries and the economic crisis of 2008 (CAMILLO, 2013; MCCARTHY, 2015; TRALDI, 2018; 2019). The outstanding new markets in the wind power field are the Asian market, with India and China, and the Latin American one with Brazil.

Considering that Brazil is one of the new frontiers in the field, this article sets out to analyze the process of wind farm installation in Brazil and, more specifically, in the country's semiarid region, focusing on the process of appropriation of the wind and the lands. The hypothesis is that production of wind power in the Brazilian semiarid region is configured as a process of 'accumulation by dispossession' (HARVEY, 2010) and more specifically by a 'green grabbing' process (FAIRHEAD et al., 2012).

The article is structured as follows: I) the presentation of a brief historical background report on the advent of the wind industry in Brazil and, more precisely, in its semiarid region; II) a discussion of the Brazilian legislation with a focus on the right to appropriate and exploit the wind; III) a presentation of the research methodology; IV) analyses of 14 wind lease contracts to demonstrate how big wind power generating companies have been appropriating the wind, the lands and the ground rent in wind power generation; and lastly V) a presentation of the paper's conclusions.

\section{The advent of the wind power industry in Brazil}

The installation of wind farms in Brazil is not merely the result of foreign wind industries need to expand, but also of Brazilian domestic factors. Among the latter are the growing domestic demand for electricity (BRASIL, 2006); the complementarity that exists between hydroelectric power and wind power (BITTENCOURT et al., 2000;

1. They took place in 1973 and 1979 with successive big increases in crude oil prices imposed by the producing countries, especially those of the Middle East that triggered the biggest fuel price and supply crisis ever recorded. 
MARINHO e AQUINO, 2011); and the Brazilian State's incentives for the expansion of renewable energies, especially after the Brazilian supply crisis ${ }^{2}$ that happened in the early years of 2000 .

Since the first decade of the $21^{\text {st }}$ century, wind energy has been expanding its part in the Brazilian electrical matrix, going from 0.03\% in 2000 (SENADO FEDERAL, 2002), to $0.2 \%$ in 2006, 1.3\% in 2012 (ANEEL, 2016) and reaching 6.8\% in 2017 (ANEEL, 2018). Even though wind power still only had a relatively small participation in the total volume of electricity generated in Brazil up until 2017, the transformations brought about by the implantation of wind farms in the Brazilian semiarid region have been tremendous and have led to new forms of land use.

The Brazilian macro-region with the greatest wind potential is the Northeast and $53 \%$ of the entire Brazilian potential is concentrated there (AMARANTE; BROWER; ZACK; SÁ, 2001). According to ANEEL ${ }^{3}$, up until the end of 2017 there were 505 wind farms representing a total verified power output of 13,145.6 MW. Of that total, 404 are located in the Northeast macro-region corresponding to $80 \%$ of such plants in operation in the country and with a verified power capacity of 10,288.2 MW, corresponding to $78.3 \%$ of all the wind power output in Brazil. The most outstanding northeastern states in terms of wind power are Rio Grande do Norte, Bahia, Ceará and Piauí. The northeastern states of Pernambuco, Paraíba, Maranhão and Sergipe also have wind farms, but in terms of installed potential they are not yet comparable to first-mentioned states as displayed in Table 1.

Table 1 - Wind farm distribution in the Brazilian Northeast Macro-region in 2017, by states

\begin{tabular}{|l|l|l|l|l|l|l|}
\hline \multicolumn{2}{|l|}{ In operation } & \multicolumn{2}{l|}{$\begin{array}{l}\text { Under construc- } \\
\text { tion }\end{array}$} & \multicolumn{2}{l|}{ Conceded } \\
\hline States & $\mathrm{N}^{\circ}$ & $\begin{array}{l}\text { Power } \\
(\mathrm{MW})\end{array}$ & $\mathrm{N}^{\circ}$ & $\begin{array}{l}\text { Power } \\
(\mathrm{MW})\end{array}$ & $\mathrm{N}^{\circ}$ & $\begin{array}{l}\text { Power } \\
(\mathrm{MW})\end{array}$ \\
\hline $\begin{array}{l}\text { Rio } \\
\text { Grande } \\
\text { do Norte }\end{array}$ & 132 & 3,558 & 23 & 561 & 3 & 71.2 \\
\hline Bahia & 90 & 2,267 & 95 & $2,033.1$ & 39 & 735 \\
\hline Ceará & 70 & 1,842 & 11 & 213 & 13 & 334.2 \\
\hline Piauí & 52 & 1,424 & 15 & 403 & 0 & 0 \\
\hline $\begin{array}{l}\text { Pernam- } \\
\text { buco }\end{array}$ & 35 & 784 & 0 & 0 & 0 & 0 \\
\hline Paraíba & 15 & 157.2 & 0 & 0 & 0 & 0 \\
\hline
\end{tabular}

2. For further information on the crisis known as the Apagão (Big Blackout) see D'Araujo, 2009; and Tolmasquim, 2011.

3- ANEEL generating information database at:

http://www2.aneel.gov.br/aplicacoes/capacidadebrasil/GeracaoTipoFase.asp. Accessed on: November 16, 2018. 


\begin{tabular}{|l|l|l|l|l|l|l|}
\hline $\begin{array}{l}\text { Maran- } \\
\text { hão }\end{array}$ & 9 & 221 & 3 & 73 & 0 & 0 \\
\hline Sergipe & 1 & 35 & 0 & 0 & 0 & 0 \\
\hline Alagoas & 0 & 0 & 0 & 0 & 0 & 0 \\
\hline Total & 404 & $10,288.2$ & 147 & $3,283.1$ & 55 & $1,140.4$ \\
\hline
\end{tabular}

Source: Elaborated by the author. ANEEL, 2018.

Of the 404 wind farms in operation in the Northeast region, 293 are located in the interior ${ }^{4}$ of the region with a total verified power output of 7,252 MW, corresponding to $70.5 \%$ of the region's entire registered output (Table 2 ).

Table 2 - Importance of the semiarid backlands in the expansion of wind power generation in the Northeast in 2017

\begin{tabular}{|c|c|c|c|c|}
\hline & & $\begin{array}{l}\mathrm{N}^{\circ} \text { of } \\
\text { wind } \\
\text { farms }\end{array}$ & Power (MW) & $\begin{array}{l}\% \text { Participation in total } \\
\text { wind power of the NE } \\
\text { region }\end{array}$ \\
\hline \multirow{4}{*}{$\begin{array}{l}\text { In opera- } \\
\text { tion }\end{array}$} & Coast & 111 & $3,036.2$ & 29.5 \\
\hline & Interior & 293 & 7,252 & 70.5 \\
\hline & $\begin{array}{l}\text { Semiarid } \\
\text { Interior }\end{array}$ & 270 & $6,639 \cdot 4$ & 64.5 \\
\hline & $\begin{array}{l}\text { NE } \\
\text { Região }\end{array}$ & 404 & $10,288.2$ & 100 \\
\hline \multirow{4}{*}{$\begin{array}{l}\text { Under con- } \\
\text { struction }\end{array}$} & Coast & 27 & 625.5 & 19.1 \\
\hline & Interior & 115 & $2,657.5$ & 80.9 \\
\hline & $\begin{array}{l}\text { Semiarid } \\
\text { Interior }\end{array}$ & 115 & $2,657.5$ & 80.9 \\
\hline & $\begin{array}{l}\text { NE Re- } \\
\text { gion }\end{array}$ & 142 & 3,283 & 100 \\
\hline \multirow{4}{*}{ Conceded } & Coast & 12 & 285.5 & 16 \\
\hline & Interior & 43 & 855 & 75 \\
\hline & $\begin{array}{l}\text { Semiarid } \\
\text { Interior }\end{array}$ & 43 & 855 & 75 \\
\hline & $\begin{array}{l}\text { NE Re- } \\
\text { gion }\end{array}$ & 55 & $1,140.4$ & 100 \\
\hline
\end{tabular}

Source: Elaborated by the author. ANEEL, 2018.

4- As a methodological resource, the study considers any wind farm located in a non-coastal municipality to be located in the 'interior'. 
Of the 404 wind farms in operation in the Northeast region, 270 (7,113 MW), that is, $65 \%$ of all the verified wind power in operation generated in the region, is located within what the old Ministry of National Integration has delimited as the Brazilian semiarid region (MINISTÉRIO DA INTEGRAÇÃO NACIONAL, 2005). Map 1 shows the importance of the interior areas of the semiarid for the expansion of the wind power industry in the Northeast macro-region.

\section{Map 1 - Municipalities with wind farms under construction, con-} ceded, or in operation in the Northeast region in 2017

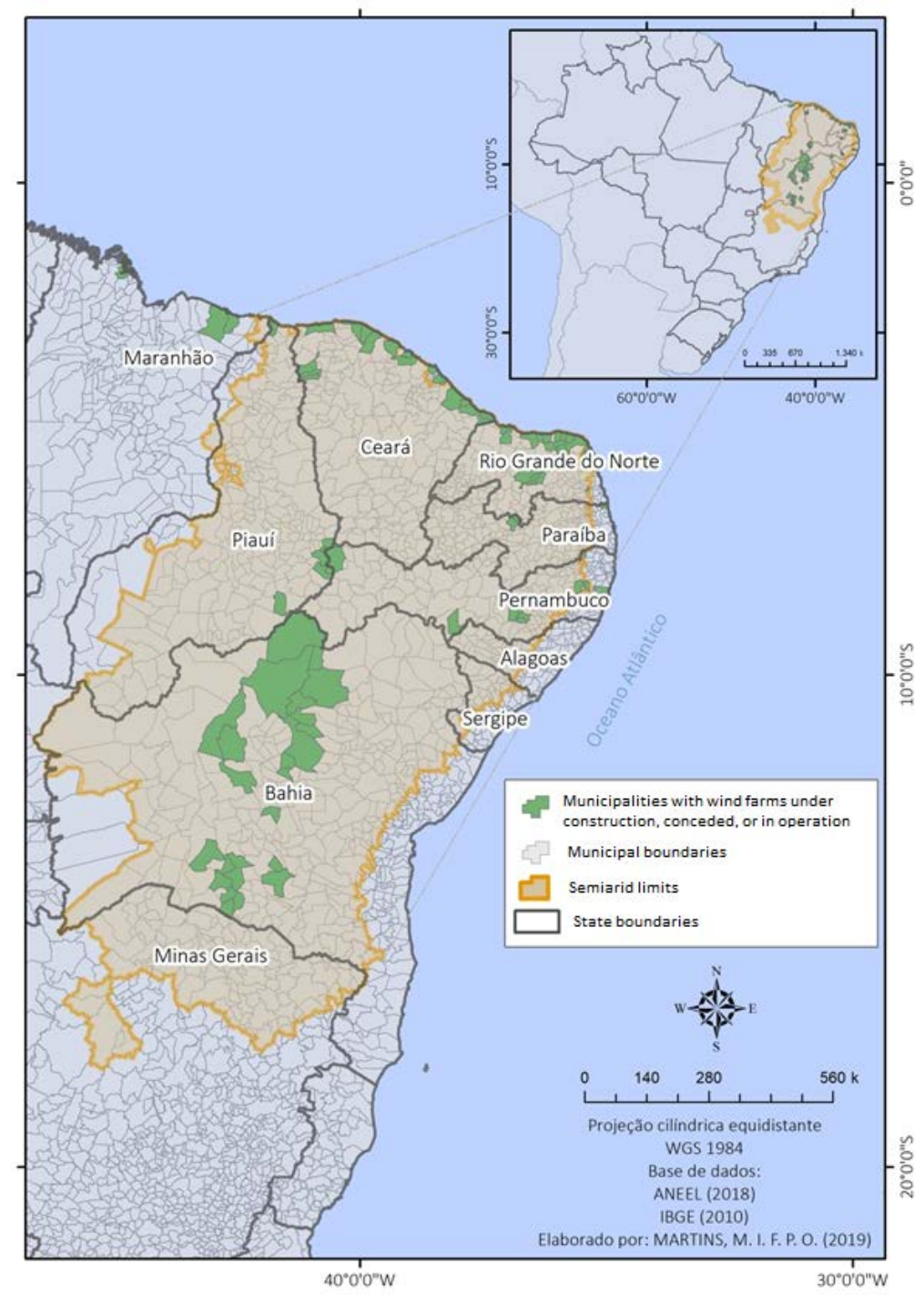

Thus, despite the fact that in the Northeast of Brazil wind farm installation began 
on the coast, it has come to be concentrated in the interior and, more precisely, in the semiarid interior where they are far more numerous and where the greater part of the generating power is installed (Table 3). That shows the tremendous importance of the semiarid region due to its high potential for electric power production in Brazil.

\section{Photos 1 and 2 - Wind farms located in João Câmara (Rio Grande do Norte) and the municipality of Caetité (Bahia), respectively}
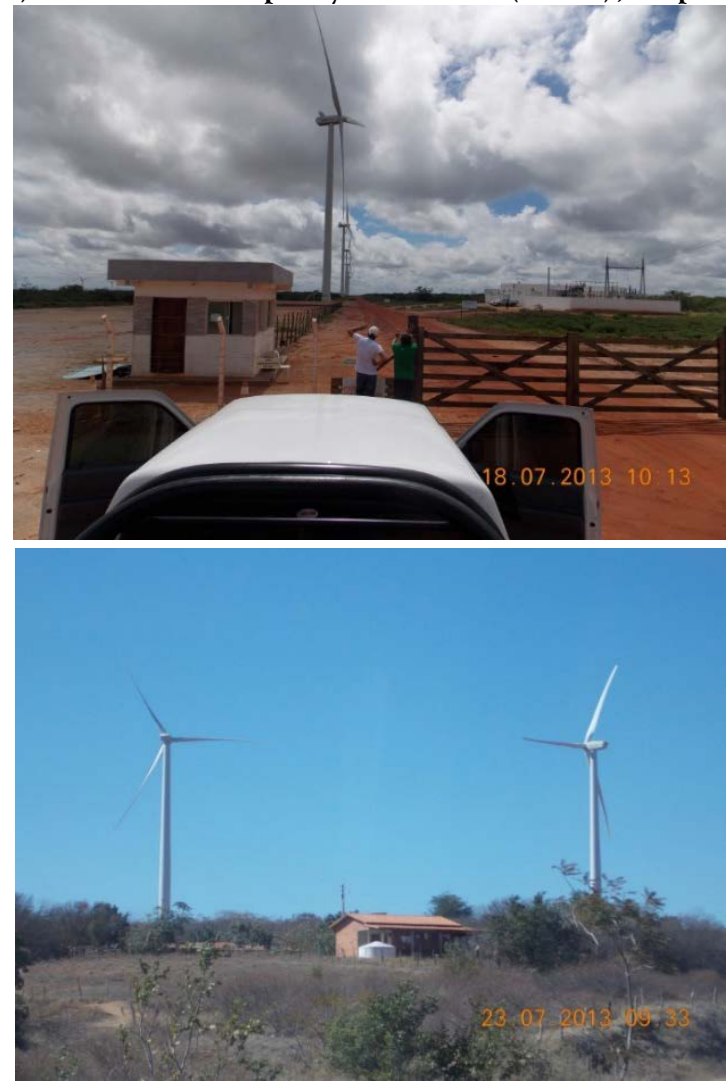

Photos by the author.

Since colonial times the Northeast of Brazil has been considered a 'marginalized' region from the point of view of capitalist expansion and appropriation except for a few areas (ANDRADE, 1973; FURTADO, 1972; PRADO JÚNIOR, 2006), so it has long remained an immense reserve of lands for future valorization.

Given the present-day technical developments, new possibilities for appropriation of the northeastern backlands have opened up. Thus not only has the wind power industry begun to appropriate areas in the region but so too has Agribusiness with the development of irrigated agriculture in the areas bordering the sub-middle course of the São Francisco river, intensive cattle-raising in the 'agreste' of the state of Pernambuco and the advance of soy crop-farming in the west of Bahia at the interface of the semiarid 
and the Cerrado biome (BACELAR, 2002; CHAVES and SANTOS, 2013).

\section{Accumulation by dispossession and green grabbing: whom does the wind belong to in Brazil?}

In Brazil electricity is mainly generated by hydroelectric plants. The source of power is the natural asset of falling water which only becomes a natural resource when it is appropriated in the form of a commodity. That conversion process occurs when the use value of elements of nature such as water, land, forests, the environment, or the space is completely ignored, and they become interesting merely in the aspect of the value attributed to them as commodities, so that their predominant value becomes their exchange value rather than their use value (RODRIGUES, 2009). Unlike thermoelectric generation whereby whoever invests in it must purchase the fuel, in wind power generation and hydroelectric generation, the capitalist who invests in them appropriates the forces of nature free of charge, benefitting from what Moore (2011) has called the 'unpaid labor' of nature.

In Brazil, water is an asset of the Federal Union ${ }^{5}$, it is a property of the State, which reserves the right to use it or decide who may use it ${ }^{6}$ and for what purposes. Thus, the state maintains its ownership of the waters guaranteeing that its private appropriation to obtain profit may occur provided that the public interest is preserved. The wind, however, is not attributed the same status. There is not even any direct mention in the 1988 Brazilian Federal Constitution (CF/88) of the moving air or of the wind.

If the $\mathrm{CF} / 88$ does not consider the Federal Union to be the owner of wind power and if wind power is not even attributed the status of an economic asset, then to whom does the wind belong and who should be granted the option of exploiting it? Brazilian Civil Law ${ }^{7}$ explicitly declares that the ownership of land extends to the heights above the land. Given the absence of any legal provision classifying wind power as a State property, as in the case of water power, the Brazilian legislation ends up attributing the ownership and the right to exploit wind power to the landowner. That makes land ownership the guarantor of unequal access to wind power because only those who own private property in areas with great wind power potential can appropriate the wind for the purpose of producing electricity.

That being so, even though the wind is a common asset insofar as it is the result of the planet's natural dynamics, its appropriation occurs to the benefit of a small group of proprietors or companies. In that sense, the appropriation of the wind for the private production of electricity in the Brazilian semiarid can be characterized as a new front of capitalist accumulation which David Harvey (2010) has called 'accumulation by dispossession'.

Harvey (2010) considers that the accumulation by dispossession process is the

5- Item II of art. 20; caput of art. 176 and its paragraphs 1 and 4 of the 1988 Federal Constitution.

6. Point b of Item XII of art. 21 of the 1988 Federal Constitution and art. 12 and its $\S 2$ of Act $\mathbf{n}^{\mathbf{0}}$ 9.433, dated 8/01/1997.

7. Art. 1.229 of the Brazilian Civil Law of 2002. 
predominant form of capital accumulation under neoliberalism and is directly related to the primitive accumulation that Marx (1996) described. Even though Marx had included a wide range of strategies among the primitive accumulation processes, such as the commodification and privatization of land, the violent expulsion of peasants, the conversion of various forms of property rights such as common, collective and State ownership into private property rights alone, colonial, neocolonial and imperial processes of asset appropriation including natural resources, the primitive accumulation is commonly generically characterized only as the appropriation and enclosure of land formerly of common use by a restricted group of people, giving rise to both capitalist private property and the proletariat (HARVEY, 2010).

Harvey (2010), considering that the accumulation strategies embraced by the primitive accumulation (MARX, 1996) are actually of a permanent nature, created the concept of accumulation by dispossession. In addition to the mechanisms that Marx described, Harvey (2010) includes under that heading corporatization and privatization of public goods and common goods such as water. According to that author, such mechanisms can liberate assets, including labor power, at a much lower cost so that the over-accumulated capital can take possession of those assets and make profitable use of them. The main objective would be the expropriation of existing spaces to find new profitable opportunities for the surplus capital.

Considering wind in its aspect as a common good which on being integrated into private property and appropriated for the production of electricity takes the form of a commodity, then its expropriation can also be included among the new accumulation mechanisms that Harvey (2010) describes and, just like water, constitute an example of dispossession and the wholesale commodification of Nature.

Given that the current stage of the respective technology cannot enable the exploitation of wind power without having towers fixed on land sites, then control over the properties with wind power potential is essential for the activity to be carried out; in other words, in order for the wind companies to appropriate the wind they must first appropriate the land. It must be underscored that the process is carried out under the pretext of producing clean renewable energy that can substitute the fossil fuels, thereby portraying itself as an important ally in combating climate change.

In that sense we can also speak of another process, green grabbing (FAIRHEAD ET AL.; 2012) whose concept originated from the concept of 'land grabbing', described as a kind of new version of the enclosure processes that Marx described (1996; 2013). The result of that process is the dispossession of rural populations, farming families, peasants and traditional populations through privatization and commodification of resources such as native pastures, water and forests. It must be stressed, however, that the land grabbing process does not always lead to the displacement or expulsion of local populations. Ever since the terms 'land grab' and 'land grabbing' entered the mainstream discussion they have been used to characterize the corporate fight for land and water in addition to more complex situations such as cases where farming families continue on the land but working on behalf of the interests of big corporations (BORRAS JR. et al., 2018, p. 7 e 8). In 
that case the corporations hold control over vast stretches of land by means of contracts whereby they determine what will be produced and how. In other words, the contracts are nothing more than instruments for exercising control of the land and, consequently, of those populations.

Thus, the green grabbing process (FAIRHEAD ET AL.; 2012) occurs when there is appropriation of land and resources supposedly for environmental reasons, that is, on the pretext of protecting the environment. In some cases, the process involves the complete alienation of the land and in others, restructuring the rules of access to resource use and management which may also have profoundly alienating effects for local populations. The process involves an enormous range of actors and alliances of actors such as: pension funds, risk capitalists, traders and commodities consultants, service providers and commercial entrepreneurs, ecotourism companies and military personnel, green activists, and others.

Hence the appropriation of the wind, earlier classified as a process of accumulation by dispossession (HARVEY, 2010), would seem to be related to the process of green grabbing (FAIRHEAD ET AL., 2012). In that sense then, the two processes complement one another and facilitate an understanding of the process of wind power generation in the Brazilian semiarid region insofar as neither one can be discussed without considering the other.

Referring specifically to green grabbing, Fairhead et al. (2012) relate it to the more general movement of capitalism in the neoliberal era that Harvey (2010) describes whereby the dispossession of local populations integrates and helps to compose broader processes of capital accumulation. For those authors the green grabbing process focuses on appropriation from the material aspect of land and resources which occurs on the pretext that economic and environmental crises demand adjustments to the capitalist mode of production.

Later we will discuss the process of land appropriation and expropriation by the wind power industries alongside the analysis of the Aeolic lease contracts.

\section{Research Methodology}

This article is the partial result of research begun in 2012 as part of a Master's degree course and was only concluded in 2019 with the defense of a doctoral thesis. Accordingly, the results displayed stem from a literature survey, fieldwork undertaken in July and August 2013 in the regions of Caetité (Bahia) and João Câmara (Rio Grande do Norte), interviews and technical visits in the same period ${ }^{8}$, and the analysis of 14 wind power lease contracts. It is important to report how difficult it is to gain access to the lease contracts. They are contracts drawn up between private entities and, although they do indirectly involve a public service concession, the Brazilian State does not participate in them. Furthermore, there is no obligation whatever for any publicizing of such contracts; quite the contrary, many of them have confidentiality clauses that specify a

8. For more detailed information see Traldi, 2014. 
fine for any of the parties that makes their content public for any reason. That clause scares the owners of the leased land and they are reluctant to talk about the contracts. It must also be underscored that the field work, reports and referenced documents and the analyzed contracts themselves showed that the contracts are pre-formulated. That means the contracts of the same company tend to be identical, only varying in some cases regarding the values of the lease payments as in the case of the CPFL Renováveis company's contracts.

In this article were analyzed 14 of the 22 contracts $^{9}$. Most of them were accessed via the ANEEL Consulta Processual (Process Consultation) platform. They were identified by chance in the midst of a plethora of generating concession processes.

Among the analyzed contracts one was of the Renova Energia Company and 13 were of the CPFL Renováveis. Those 13 contracts were absolutely identical except for the clause determining the calculation of the value to be paid for the lease. Based in those differences those 13 contracts were divided in three typ e

In the first and in the second types of contracts the calculation is based on the wind power generating capacity of the specific individual property and the third defines the value on the basis of the gross revenue of the wind farm.

In the case of the CPFL Renováveis contracts, which refer to the wind farm Morro dos Ventos, the calculation specified in the contracts was applied to the total amount the company received in reals for the year 2017. For that it was necessary to combine contract information with information on the monthly and yearly production of the wind power complex as a whole, the value received for the electricity produced in reals per MW for each wind farm, the number of towers, the power output of each tower, the power potential of the wind farm and/or wind power complex, and the number of leased properties.

The information on each aspect is not made publicly available as a set and is not easy to find on the ANEEL site or in the National Operator of the Electricity System (Operador Nacional do Sistema Elétrico - ONS). It proved necessary to survey different platforms and combine the information and to require access to information based on the Access to Information law.

From the Electricity Commercialization Chamber (Câmara de Comercialização de Energia Elétrica - CCEE) we were able to obtain data on: the dates and identification of the electricity generating concession auctions in which each wind power company had been the winning bidder; the municipality and state where each wind farm was located; the identification of the wind farm proprietor company; the power output of each farm in MW; the date of the beginning and the end of electricity supply; and the sale price ${ }^{10}$ on the date of the auction (R $\$ / M W h)$.

9 - Consultation of the CPFL Renováveis contracts: Consulta Processual ANEEL, Processes n. 48500.001161/2010-96, Vol. 00002, pp. 122 to 127; n. 48500.001159/2010-17, Vol. 00002, pp. 161 to 167; and n. 48500.001160/2010-41, Vol. 00002, pp. 179 to 185 . Consultation of the Renova Energia contract in Traldi, 2019 pp. 330 to 337

10. This information was confronted and complemented with that obtained on ANEEL PARACEMP platform where the shareholder composition of each wind farm can be consulted. 
The information obtained from the ONS was the amount of electricity produced in 2017 by each one of the wind farms that integrate the overall wind power set for the twelve months of the year, obtained from the Monthly Wind Power Generation Bulletins (Boletins Mensais de Geração Eólica ${ }^{11}$ ). With the data on total electricity production for the year 2017 and on the sale prices registered in the auctions ( $\$ / M W h$ ), adjusted by the IPCA index (economic indexer adopted by the official auction tender documents), it was possible to know how much each company received for the sale of electricity in 2017.

To find out how much those who leased their properties to the wind power companies received in 2017 for doing so, the amounts paid were calculated property by property and then they were all added together. For contract types 1 and 2 , the calculation of the lease amount only considers the power rating and the number of towers installed on a given property so what need to be known was: i) installed generating capacity per tower; ii) number of towers/property/contracts; iii) the lease value calculation formula specified in each of the lease contracts that is part of the overall wind power $\operatorname{set}^{12}$. For the third type pf contract in which the calculation is a fraction of the gross income of the farm, it was necessary to calculate the gross income received by the respective company from the towers located on the property in question and that had already been calculated when calculating the company's gross income for 2017. Thus it was merely necessary to confront the company's total gains in 2017 with the amount paid out to the landowners in the same year.

It is important to explain that there is a certain fragility in the results presented here insofar as the type 3 contracts indicate that the payment will be a percentage of the turnover after tax and social security deductions and that aspect, we were unable to calculate.

Lease contracts and the appropriation of wind, land and of the ground rent the companies

In Brazil access to and control of properties for wind power generating is achieved in two ways: the acquisition/purchase of properties with high wind power potential by investment companies which has come to be a less expressive way; or by means of land lease agreements for wind power generating purposes; the predominant way in which it takes place.

The wind power land lease contracts are bilateral and governed by private law legislation; that is to say, only the two parties directly involved participate and there is no interference whatever from any sphere of the Brazilian state (TRALDI, 2018). However,

11 - Available at: http://www.ons.org.br/paginas/conhecimento/acervo-digital/documentos-e-publicacoes?categoria=Bo letim + Mensal+de+Gera\%C3\%A7\%C3\%A3o+E\%C3\%B3lica.

12 - Contracts available for consultation at Consulta Processual on the ANEEL site: process n. 48500.005634/2010-24, Volume 2, pp. 178 and those following. Available at: http://www.aneel.gov.br/consulta-processual. Accessed on: 11/12/2018. 
the mere possession of a lease contract is not sufficient, on its own, to guarantee that the conceding authority will concede the right to generate power to the winning company in the tendering auction because there is a series of documents that ANEEL requires for that to occur. Among which is proof that both the property in question and the wind power generation lease contract are legally registered ${ }^{13}$. That situation of the property being correctly registered is actually quite uncommon among most of the smaller Brazilian municipalities.

In the region of João Câmara (Rio Grande do Norte) and Caetité (Bahia), Brazil's leading wind energy-producing municipalities, the advent of the first wind power companies triggered a rush to buy and, even more, to lease land, heating up the local land market in their rural areas (TRALDI, 2014). The land rush was associated to a series of denunciations of illegal commandeering of land, land registry office frauds, expulsion of rural inhabitants and disrespect for the traditional ways of life of the local populations on the part of the wind power companies (COMISSÃO DA PASTORAL DE TERRA DA BAHIA, 2012; 2013; HOFSTAETTER, 2016; TRALDI, 2019).

Land tenure issues in Brazil that existed long before the advent of the wind power projects seem to have complicated the situation even more. João Câmara, for example, is among the municipalities in the state of Rio Grande do Norte that concentrate the greatest installed wind power capacity. According to the Agriculture and Livestock Census (Censo Agropecuário) for 2006 (BRASIL, 2006) it is also one of the municipalities where most of the people acquired their rural properties through agrarian reform schemes or resettlement programs. Furthermore, it should be noted that many of the properties up until 2006 had no land titles at all (SANTOS, 2012). Furthermore, João Câmara is part of the Baixa Verde micro-region typified as a region where land ownership is highly concentrated (SANTOS, 2012). The situation of being squatters on the land is a very precarious one in regard to exercising the right to ownership and makes such individuals even more vulnerable to being dispossessed of their land and their rights when faced with the economic power of the big wind power companies and that of the local and regional political elites.

The reports and denunciation of populations being expelled from their lands, of the coopting and deceiving of local leaders with false promises, illegal possession and registration of land, land registry frauds, disrespect for the rights and traditions of local populations that appeared, not only in the reports publicized by the CPT-Bahia but in the work of Traldi $(2014 ; 2019)$ and of Hofstaetter (2016), also seem to corroborate the thesis that the arrival of the wind power industry in the Brazilian semiarid by means of violence and illegalities configures, in the broader sense, a process of accumulation by dispossession and in a narrower sense, one of green grabbing (FAIRHEAD et al., 2012). However, the present article limits itself to the analysis of the wind power leasing contracts and how, despite their apparent legality, they also foster the appropriation and expropriation of the wind and the land.

Contact duration is another aspect that seems to corroborate that thesis considering 
that, in some cases, they have a duration of 49 years with automatic renewal for another successive 22 without any need for the consent of the owner of the land (BAUER, 2013). The more common durations are from 25 to 30 years with automatic renewal for an equal period should the company wish and again without any need for the owner's consent.

The long duration foreseen in the contracts and the existence of an automatic contract renewal clause would seem to indicate that, despite the fact that they continue to be the formal owners of the land as the title of the properties is registered in their name, the lessors actually lose control over their land for very long periods of as much as 70 years. In those terms the lease contracts for wind generation purposes could be considered as being the complete alienation of the property given that control over it is lost for generations. Even though the wind power generating companies declare that the lessors are free to carry on using the rest of the property for other activities, provided they do not have a negative effect on the generating installations, Traldi (2014) and Hofstaetter (2016) have found the situation to be very different. Those authors report that many of the properties are fenced off by the companies and no activity other than wind powered generation of electricity takes place on them.

Another important aspect that underscores the argument that the lease contracts can be considered as the total loss of control over the property on the part of the owners is that, in addition to the long duration foreseen for the contracts, there is a clause that stipulates a unilateral fine in the event that the owner of the land decides to withdraw from the deal. The contract rescission fines are to the order of five to twenty million reals (BAUER, 2013; TRALDI, 2018). Should the companies decide to desist from the contract however, they merely need to give the proprietor 30 days prior notice and they will be relieved of all their contractual bonds. There are even contracts with terms that describe them as unretractable and irrevocable and that the validity of the contracts and their terms extend to the inheritors of the property or whoever succeeds to its ownership, even though such clauses are actually illegal.

There is also a secrecy clause in the contracts binding the parties whereby the proprietors of the lands are forbidden to make the contents of the contracts publicly known. That kind of clause makes dialogue among the families that have signed the contracts or are thinking of signing them unfeasible, thereby hampering the possibility of any collective organization of the proprietors to try and obtain better contractual conditions for all.

The result is that the contracts are pre-formatted in regard to almost all the clauses which are always more advantageous to the companies than to the land proprietors and they differ only in some case in the details of calculations of the value to be paid by the lessee for the leasing of the land. That leads to wildly disparate payments for land leases for the installation and operation of the same wind farm or within the same wind power complex.

Although the companies declare that the amounts that they pay to lease the land are directly related to the amount of electricity produced and use the same argument to consider the payment as being royalties such as those paid for crude oil extraction or 
energy generated using water resources ${ }^{14}$, that affirmation is questionable because some companies determine their contracts based on a fixed annual payment per tower without establishing any relationship to the production capacity. It is important to point out that even though a company establishes a value per individual tower, they actually lease the entire property and not just the part on which the tower stands. Table 4 presents a summary of the 14 contracts analyzed by this study.

Table 4: Lease values paid by wind power companies in 2017

\begin{tabular}{|c|c|c|c|c|c|c|}
\hline \multirow{2}{*}{$\begin{array}{l}\text { Wind Power } \\
\text { company }\end{array}$} & \multirow[t]{2}{*}{$\begin{array}{l}\text { Corpora- } \\
\text { te Group }\end{array}$} & \multirow{2}{*}{$\begin{array}{l}\text { Land rent } \\
\text { paid/to- } \\
\text { wer/ } \\
\text { month* } \\
\text { (In R\$) }\end{array}$} & \multirow{2}{*}{$\begin{array}{l}\text { Con- } \\
\text { tract } \\
\text { signatu- } \\
\text { re year }\end{array}$} & \multirow{2}{*}{$\begin{array}{l}\text { Munici- } \\
\text { pality }\end{array}$} & \multicolumn{2}{|c|}{$\begin{array}{l}\text { Installed wind } \\
\text { driven generating } \\
\text { capacity in the } \\
\text { semiarid interior }\end{array}$} \\
\hline & & & & & MW & $\%$ \\
\hline Renova Energia ${ }^{15}$ & $\begin{array}{l}\text { Cemig } \\
\text { (Brazi- } \\
\text { lian) }\end{array}$ & 684.46 & 2011 & $\begin{array}{l}\text { Caetité } \\
\text { (BA) }\end{array}$ & 202.5 & 3.04 \\
\hline
\end{tabular}

\section{CPFL Renová-}

veis $^{16}$

\begin{tabular}{|c|c|c|c|c|c|}
\hline Type 1 Contract (5) & State & 900.00 & 2009 & João & \\
\hline $\begin{array}{l}\text { Type } 2 \text { Con- } \\
\text { tract (1) }\end{array}$ & (Chine- & 750.00 & 2008 & $\begin{array}{l}\text { Câmara } \\
(\mathrm{RN})\end{array}$ & 7.84 \\
\hline $\begin{array}{l}\text { Type } 3 \text { Con- } \\
\operatorname{tract}(7)\end{array}$ & & $1,122.99$ & 2009 & & \\
\hline
\end{tabular}

Source: Elaborated by the author. Consulta Processual ANEEL.

The contract proposed by the Brazilian company Renova Energia company, part of the Cemig group over which the Minas Gerais has shareholder control, is an example of a contract whereby the lease rent value is established without any reference to the respective electricity production potential. The document refers to a property of approximately 230 hectares of land located in the rural area of the municipality of Caetité in the state of Bahia. It was signed in 2011 and the value established for leasing the area was $R \$ 5,500$ reais a year per tower ( $R \$ 458.33$ tower/month in values of 2011$)$ which,

14 - In hydraulic generation, there are two types of payment for financial compensation: the Financial Compensation for Exploitation of Water Resources (CFURH) and the payment of royalties to the Itaipu Hydroelectric Power Plant (FARIAS, 2010). In both cases, payment is based on production.

15 - This contract can be found in Traldi, 2019 pp. 330 to 337.

16 - Access to contracts in: ANEEL Procedural Consultation, Process n. 48500.001161/2010-96, Volume 00002, pp. 122 to 127; Process n. 48500.001159/2010-17, Volume 00002, pp. 161 to 167; and Process n. 48500.001160/2010-41, Volume 00002, pp. 179 to 185. 
in more up to date values ${ }^{17}$, would be the equivalent of $\mathrm{R} \$ 8,213.59$ (Table 4). In other words, the value established as payment for the lease of the land has no connection to the electricity production volume whatever. Presently the Renova Energia company has a generating capacity installed in the interior of the semiarid region of $202.5 \mathrm{MW}$ which corresponds to $3.04 \%$ of the entire installed capacity in the semiarid interior. However, the company, one of the pioneers in the implantation of wind farms in the state of $\mathrm{Ba}$ hia, specifically in the Caetité region in western Bahia, once had a far greater percentage participation in the total installed capacity. In 2016, it had an installed generating capacity of approximately $652.1 \mathrm{MW}^{18}$ and a further $525.9 \mathrm{MW}$ under construction (RENOVA ENERGIA, 2017). In the face of a liquidity crisis that began in 2016, it sold off a considerable part of its wind power generating stock in the period 2017-2018. On doing so Renova Energia signed a contract conceding its leasing rights to the companies that purchased their shares passing the lease contracts into the hands of the purchasers without any alteration to the original terms. Thus it is probable that the contracts of the fixed-term type are in force in a far greater number of properties than the number that the company still operates with today.

Renova Energia was not the only one to link payment for leasing land to production. Contracts which today are in the hands of CPFL Renováveis associate part of such payments to the amount of installed generating capacity and not to the production/ energy sale per tower. It must be pointed out that those contracts were first signed by the company Desa-Dobravê which became a subsidiary of CPFL in 2014.

CPFL Renováveis is part of CPFL Energia and in 2017 the Chinese state corporation State Grid acquired a majority holding of its shares. It currently holds shareholder control over 521.36 MW of installed capacity in the Brazilian semiarid interior corresponding to $7.84 \%$ of the total for the region. It is the fourth largest of the wind power generating companies in the region. The situation in its specific case is even more complicated because a single wind-generating complex, the Conjunto Eólico Morro dos Ventos located in the rural zone of João Câmara, Rio Grande do Norte, is made up of the wind farms Morro dos Ventos I, III, IV, VI and IX, with an installed capacity of $144 \mathrm{MW}$ and 80 towers, distributed in 13 different land properties. In them we found three different types of contracts in force but with the differences being restricted to the calculation of the rent value to be paid to the owners of the land.

In the first type of contract, the rent value for payment in the operational stage was $1 / 12$ of $\mathrm{R} \$ 6,000$ reais for each MW of installed generating capacity, per month (which in practice came to be $\mathrm{R} \$ 900.00$ per tower per month) in 2017. That contract was applied to five properties and a total of 24 towers. In the second type of analyzed contract the proposed rent payment calculation for the operational stage was $1 / 12$ of $R \$ 5,000$ reals for each MW of installed generating capacity per month (which in practice came to be $\mathrm{R} \$ 750.00$ per tower per month) in 2017. In the third type of contract, the only one of

17 - Update based on the IPCA (IBGE), index chosen by the contract, until December 31, 2017.

18 - Which corresponded to $8.6 \%$ of all installed power in operation in the Northeast region and $37.9 \%$ of all installed power in operation in the state of Bahia, in 2016 (ANEEL, 2016). 
the three that actually associated lease payment to effective production, the value paid in the operational stage was $0.85 \%$ of the gross income of the wind farm installed on the respective property. That resulted in a payment of $\mathrm{R} \$ 1,122.99$ per tower, per month, also in 2017.

This last contract modality was in force in seven properties with a total of 47 towers. Also in this case, the company that owned the wind farms, CPFL Renováveis (formerly Desa-Dobreve $\hat{~}^{19}$ ), is not the same company as the one that signed the lease contracts with the landowners; a third company, Companhia Valença Industrial intermediated the contracts and later drew up a contract conceding its lease rights to the wind farm owners. For its intermediation, the Companhia Valença Industrial has a right to 0,65\% of the gross income from the wind farms, after tax and social insurance deductions, for the next 37 years, the duration stipulated in the original land-lease contracts. Presently the CPFL Renováveis company has a generating capacity installed in the interior of the semiarid region of $521.36 \mathrm{MW}$ which corresponds to $7.84 \%$ of the entire installed generating capacity in the semiarid interior. As mentioned above, CPFL Renováveis is the fourth largest company in the region in terms of installed capacity which means that its contracts, or most of them follow the same pattern as the first and second types so that a considerable number of landowners located in the semiarid interior of the Northeast may be receiving lease rent for their land that has no direct relation to the amount of electricity generated or the size of the leased area.

However, it could be argued that in spite of all that has been set out above, the payment of the lease rents could be seen as a compensation and that the landowners are receiving the ground rent (MARX, 2017; KAUTSKY, 1968). Given that the possession of the land is a presupposition for the production of wind powered electricity generation to occur and that the towers have to be fixed to the ground, then it could be expected that the owners of the land would indeed have a participation in the capitalist accumulation process.

Traldi (2014) reports that there are some landowners who declare themselves to be quite satisfied with the advent of the wind power companies and commemorate the leasing of their lands for that activity. That shows how, contrary to the denunciations of dissatisfaction on the part of some of the earlier-mentioned groups, there are other social groups who are satisfied with having been incorporated to the production of windgenerated electricity by means of the leasing contracts. It must be questioned, however, whether that incorporation of the proprietors in the global value chain of electricity production is not, at the same time, a process that excludes them from the process of capitalist accumulation, a phenomenon which Hickey and du Toit (2013) have referred to as 'adverse incorporation'.

To gain an understanding of how and in what terms the property owners in the interior of the Brazilian semiarid are indeed incorporated to the electricity production chain and the dimensions of that inclusion in the capitalist accumulation process we made a survey of the proprietors' gains in comparison with those of the wind power companies

19- Desa-Dobrevê which later became a subsidiary of CPFL Renováveis. 
in the year 2017. For the purposes of this article, the data presented refer to a single wind complex but the calculations for other wind power complexes can be found in Traldi (2019)

The Morro dos Ventos complex had a gross annual turnover of $\mathrm{R} \$ 126,832,257.78$ in 2017. According to this study's calculations, in that same year the amount paid to land proprietors corresponded to just $0.91 \%$ of the company's gross income. Thus, despite the landowners having leased out their entire properties for the wind drive generation of electricity, an area totaling 2,628.87 hectares and having made a series of other subsistence and income-producing activities unfeasible, their participation in the gross income of the generating activity is less than $1 \%$. On the other hand, the company that merely intermediated the transfer of the contracts and takes no responsibility for any activity or counterpart whatever, received payment of $\mathrm{R} \$ 824,409.68$ (0.65\%). Even though the ground rent, in the Marxist sense cannot be quantified in those terms, the values indicate that the landowners are not receiving the ground rent as income from the land and that their incorporation into the capitalist accumulation process is proceeding with a marginal configuration as it were described by Hickey and du Toit (2013) as 'adverse incorporation'.

\section{Conclusions}

Ownership of land with great wind potential is a prerequisite asset for generating wind powered electricity and the wind lease contracts, at least in Brazil, are predominantly those providing access to the property. The contracts are instruments of unrestricted control over the property and are structured to achieve that end.

In that sense, the long durations of their validity and the use limitations and restrictions imposed on the landowners, the clauses stipulating unilateral fines with values in the millions should the land owners wish to withdraw from the contract and the formal imposition of secrecy and confidentiality regarding contract contents which hampers any possibility of collective organization among the land proprietors whereby they might be able to negotiate more favorable terms are effectively mechanisms for exercising control over the land and at the same time, mechanisms of appropriation and expropriation of the wind and the land.

The wind power lease contracts are clearly more advantageous for the companies than for the land proprietors: there is a notably great contractual inequality between the parties to the detriment of the landowners. In addition to being restricted from negotiating, the fine values and the excessively long durations of contract validity, the landowners cannot even negotiate the amounts to be paid by the companies for the use and control of the properties and, furthermore, all taxes and fiscal obligations associated to the ownership of the land are the onus of the proprietors. In other words, the contracts that have been signed endow the companies with total freedom to generate electricity with little or no risk, paying whatever amounts they consider convenient.

We would underscore two important processes triggered by the implantation and operation of wind farms in the interior of Brazil's semiarid region. In regard to the appropriation of the wind, we believe we are witnessing a process of accumulation by 
dispossession that occurs when a natural asset, the wind, a common good, is appropriated by the private sphere inaugurating new forms of wholesale commodification of nature.

These new commodification fronts have been made possible by the science and technology dedicated to the wind power sector which has made the appropriation of the wind to produce electricity on a commercial scale feasible. However, the limitations of the possibility of exploiting winds on high without a base on the ground have meant that vast areas of land have had to be appropriated to fix, in the ground, the towers that capture the wind. Added to that there is the climate change crisis and the fact that wind energy has been elected to replace fossil fuels. That explains why the implantation and operation of wind farms worldwide has been taking place on the pretext of producing energy that can be considered clean and renewable. Given all that has been set out above, it can be concluded that the process of expropriation and commodification of the wind takes place alongside a process of dispossession and expropriation of land for environmental green grabbing purposes because the energy industry is appropriating vast areas on the pretext of expanding energy production in the mold of a sustainable market. In some cases that process translates itself as a complete alienation of the land and results in the expulsion of local populations and, in others, the restructuring of the access and use rules curbs the extant forms of social reproduction and for that reason may have profoundly alienating effects for the local populations.

Regarding the rental payments for the leased lands we can safely state that there is diversity in the forms of the companies' remuneration of the lessors. It cannot be said that the wind power companies in Brazil remunerate the proprietors of the lands they use on the basis of electricity production and that makes it hard to associate their payments with the category of royalties in the way that it takes place in generating plants in Brazil based on fossil fuels, coal or hydroelectric sources.

In the light of the analyzed contracts and based on the role played by the owners leasing land to the wind power companies in the process of capitalist accumulation, we have grounds for believing that a process of adverse incorporation is in course. That is because the landowners hand over their main asset, which is their wind power potential, to the companies but enjoy a participation in the annual gross income of the latter of less than $1 \%$.

The analysis of the implantation and operation of wind power generating plants in the interior of the Brazilian semiarid region shows that history is being repeated in the form a tragedy because at the same time that the benefits of wind-based generation are being praised, as indeed they should be, given their importance in the fight against climate change, there is no analysis made of the spatial transformations that stem from the dispossession of the wind and the expropriation of the land which are consequences of the way in which the process is being organized. Thus, what must be questioned is not the source of energy or the generating technology as such but rather, the form of organization of the activity and the use that the wind power industry makes of points and patches of land in the interior of the Brazilian semiarid region. 


\section{References}

AGÊNCIA NACIONAL DE ENERGIA ELÉTRICA (ANEEL). Banco de Informações de Geração de Energia. 2016. http://www.aneel.gov.br/area.cfm?idArea=15. Acesso em: 08/12/2016.

AGÊNCIA NACIONAL DE ENERGIA ELÉTRICA (ANEEL). Banco de informação de geração. Brasília, DF, 2018. Disponível em: http://www2.aneel.gov.br/aplicacoes/capacidadebrasil/ GeracaoTipoFase.asp. Acesso em: 16 fev. 2018.

AMARANTE, O. A. C.; BROWER, M.; ZACK, J.; SÁ, A. L. Atlas do potencial eólico brasileiro. Ministério de Minas e Energia Eletrobrás, 2001. Disponível em: http://www.cresesb.cepel. br/publicacoes/download/atlas_eolico/Atlas\%20do\%20Potenci al\%20Eolico\%20Brasileiro.pdf. Acesso em: 15/10/2013.

ANDRADE, M. C. de. A Terra e o Homem no Nordeste. Editora Brasiliense, São Paulo: 1973.

ARAUJO, Tânia Bacelar. NORDESTE, NORDESTES: que nordeste? In: Observanordeste. Fundação Joaquim Nabuco, 2002. Disponível em: https://www.fundaj.gov.br/index.php/ ultimas-noticias/192-observanordeste/observanordeste/2113-nordeste-nordestes-que-nordeste. Acesso em: 01/09/2020.BAUER, T. Energia Eólica: a caçada pelos ventos. Comissão Pastoral da Terra Bahia. Documentário. Maio de 2013. Disponível em: https://www.youtube.com/ watch? $=$ s90nKSlbgoQ. Acesso em: 10/02/2019.

BITTENCOURT, ROGÉRIO MOTTA et al. Sistemas Complementares de Energia Eólica e Hidráulica no Brasil, Comisione de Integración Eléctrica Regional. Comité Nacional Área de Generación \& Transmisión. Congreso CIER, Buenos Aires, 2000.

BRASIL, IBGE. Censo Agropecuário, 2006. Rio de Janeiro, RJ, 2006. Disponível em: < https:// ww2.ibge.gov.br/home/estatistica/economia/agropecuaria/censoagro/2006_segunda_apuracao/ default.shtm >. Acesso em: 20 abr. 2019.

BRASIL. Empresa de Pesquisa Energética. Plano Nacional de Energia 2030. Rio de Janeiro: EPE, 2006. Disponível em: http://www.epe.gov.br/PNE/20080111_1.pdf. Acesso em: 10/07/2018.

CAMILLO, E. V. As políticas de inovação da indústria de energia eólica: uma análise do caso brasileiro com base no estudo de experiências internacionais. (tese de Doutorado), Universidade Estadual de Campinas. Instituto de Geociências, 2013.

COMISSÃO DA PASTORAL DA TERRA-BA. Quilombolas de Caetité na luta contra a instalação de parques eólicos. Publicação: 09/2012. Disponível em: http://quilombolasdopiemonte.blogspot.com.br/2012/09/quilombolas-de-caetite-na-luta-contra.html>. Acesso em: 24/09/2012.

CHAVES, M.L.J. e SANTOS, C.D. Agronegócio da fruticultura e da soja: a territorialização de empresas agrícolas nos cerrados e vales úmidos do nordeste brasileiro. Revista GeoUECE - Programa de Pós-graduação em Geografia da UECE Fortaleza/CE, v.2, no3 3, p.118-141, jul./dez. 2013. Disponível em http://seer.uece.br/geouece 
COMISSÃO DA PASTORAL DA TERRA-BA. O avanço do capital e sua influência nos modos de vida das populações tradicionais no município de Caetité (BA). Publicação: 13/08/2013.<https://www.cptnacional.org.br/index.php/publicacoes-2/ noticias-2/15-artigos/1676-o-avanco-do-capital-e-sua-influencia-nos-mo-dos-de-vida-das-populacoes-tradicionais-no-municipio-de-caetite-ba>. Acesso em: 07/08/2017.

D’ARAUJO, R. P. Setor elétrico Brasileiro. Uma aventura mercantil. Brasília: Confea, 2009.

DUTRA, R. M. Viabilidade Técnico-Econômica da Energia Eólica Face ao Novo Marco Regulatório do Setor Elétrico Brasileiro. (Dissertação de Mestrado), Universidade Federal do Rio de Janeiro no Instituto Alberto Luiz Coimbra de Pós-Graduação e Pesquisa de Engenharia COOPE/UFRJ. Rio de Janeiro, 2001.

FAIRHEAD. J.; LEACH, M.; SCOONES, I. Green Grabbing: a new appropriation of nature? Journal of Peasant Studies, 2012. v. 39, No. 2, p. 237-261.

FARIAS, A. R. Uso do território e federação brasileira: os casos das compensações financeiras associadas ao petróleo e gás natural (royalties), recursos minerais (CFEM) e recursos hídricos (CFURH). 2011. (171 p.) Dissertação (mestrado) - Universidade Estadual de Campinas, Instituto de Geociências, Campinas, SP. Disponível em: http://www.repositorio.unicamp.br/ handle/REPOSIP/286936. Acesso em: 1 Sep. 2020.

FURTADO, C. A Formação Econômica do Brasil. São Paulo: Companhia das Letras, 1972.

HARVEY, D. O novo imperialismo. 4. ed. São Paulo, SP: Edições Loyola, 2010. 201p.

HICKEY S.; DU TOIT, A. Adverse Incorporation, Social Exclusion, and Chronic Poverty. In: Andrew SHEPHERD, A.; BRUNT, J. Chronic poverty: concepts, causes and policy. Palgrave Macmillan, 2013. pp.134-139.

Kautsky K. A questão agrária. Tradução de C. Iperoig; Apresentação de Moniz Bandeira. Rio de Janeiro, RJ: Laemmert; 1968.

MARINHO, M. H. N.; AQUINO, R. R. B. Oferta de energia através da complementariedade sazonal hidro-eólica. Revista PCH Notícias \& SHP NEWS. N. 40, ano 2011. Disponível em: https://cerpch.unifei.edu.br/wp-content/uploads/revistas/revista-40. pdf $\#$ page=36. Acesso em: 05/10/2018.

MARX, K. "A Assim Chamada Acumulação Primitiva”. In: "O Capital”. Nova Cultural, São Paulo: 1996.

MARX, Karl. O capital: crítica da economia política. Tradução de Rubens Enderle. São Paulo, SP: Boitempo, 2013- .

MARX, Karl. O capital: crítica da economia política. Tradução de Rubens Enderle. São Paulo, SP: Boitempo, 2017 -. 
MCCARTHY, J. A socioecological fix to capitalist crisis and climate change? The possibilities and limits of renewable energy. Revista Environment and Planning. 2015, v. 47, p. 2485 - 2502.

MINISTÉRIO DA INTEGRAÇÃO NACIONAL. Secretaria de Políticas de Desenvolvimento Regional. Nova delimitação do semi-árido brasileiro. Brasília: MIN, 2005. Disponível em: http://www.mi.gov.br/c/document library/get_file?uuid=0aa2b9b5-aa4d-4b55-a6e182faf0762763\&groupId=24915. Acesso em: $15 / 10 / 2018$.

MOORE, J. W. Transcending the metabolic rift: a theory of crises in the capitalist world-ecology. The Journal of Peasant Studies, 38: 1, 2011. pp. 1-46.

PRADO JÚNIOR, C. História Econômica do Brasil. São Paulo: Editora Brasiliense, 2006.

RENOVA ENERGIA. Release de resultados 4t16. 2017. Disponível em: http://ri.renovaenergia. com.br/listresultados.aspx?idCanal $=$ mTI45Afdlnx8JP30Yg9VWg $==$. Acesso em: 28/02/2018.

RODRIGUES, A. M. A abordagem ambiental: Questões para reflexão. GeoTextos, v. 5, n. 1, jul., 2009. p.183-201

SANTOS, R. A. V. Concentração da posse da terra e o Programa Nacional de Crédito Fundiário: uma análise para o Estado do Rio Grande do Norte, 2006 - 2012. 142 f. Dissertação (Mestrado em Economia Regional) - Universidade Federal do Rio Grande do Norte, Natal, 2012. Disponível em: https://repositorio.ufrn.br/jspui/handle/123456789/14083. Acesso em: 08/08/2019.

SENADO FEDERAL. Crise de Abastecimento de energia Elétrica- Relatório Final n.2 de 2002 CN. Congresso Nacional. Brasília, 2002. Disponível em: http://legis.senado.leg.br/sdleg-getter/ documento?dm=3951259\&dispositi/on=inline. Acesso em: 19/11/2018.

SMITH, N. Desenvolvimento desigual: natureza, capital e a produção de espaço. Rio de Janeiro: Bertrand Brasil, 1988.

TOLMASQUIM, M. T. Novo modelo do setor elétrico brasileiro. Rio do Janeiro: Synergia; EPE: Brasília, 2011.

TRALDI, M. Acumulação por despossessão: a privatização dos ventos para a produção de energia eólica no semiárido brasileiro. 2019. (378 p.). Tese (doutorado) - Universidade Estadual de Campinas, Instituto de Geociências, Campinas, SP. Disponível em: http://www.repositorio.unicamp.br/handle/REPOSIP/335160. Acesso em: 09/03/2020.

TRALDI, M. Os impactos socioeconômicos e territoriais resultantes da implantação e operação de parques eólicos no semiárido brasileiro. Scripta Nova. Revista Electrónica de Geografía y Ciencias Sociales, Barcelona, v. XXII, n. 589. 2018. Disponível em: http://revistes.ub.edu/index. php/ScriptaNova/article/view/19729/23618. Acesso em: 10/09/2018. 


\section{Mariana Traldi}

$\checkmark$ mariana.traldi@ifsp.edu.br

ORCiD: https://orcid.org/0000-0002-1837-8170
Submitted on: $28 / 04 / 2020$

Accepted on: 06/05/2021

2021;24e:00522

How to cite: TRALDI, M. Accumulation by dispossession and green grabbing: wind farms, lease agreements, land appropriation in the Brazilian semi-arid. Ambiente $\mathbb{E}$ Sociedade. São Paulo, v. 24, p. 1-22, 2021. 


\title{
Acumulação por despossessão e green grabbing: parques eólicos, arrendamento e apropriação de terras no semiárido brasileiro
}

\author{
Mariana Traldi
}

São Paulo. Vol. 24, 2021

Tema em destaque: Insurgências Decolonais e Horizontes Emancipatórios: Contribuições da Ecologia Política
Resumo: A geração de energia eólica é recorrentemente apresentada como uma das alternativas ao uso de combustíveis fósseis, desempenhando por isso importante papel no combate as mudanças climáticas. Neste contexto, o interior semiárido brasileiro emerge como uma nova fronteira para expansão da indústria eólica dado seu elevado potencial. Sendo o proprietário da terra também proprietário do vento no Brasil, buscou-se compreender como se dão os processos de apropriação do vento e de terras para a produção de energia eólica a luz dos conceitos de acumulação por despossessão e green grabbing. Para tanto, foram analisados 14 contratos de arrendamento eólico. Concluiu-se que: os contratos de arrendamento são o instrumento legal que viabiliza a apropriação do vento e de terras; que a apropriação do vento se trata de um processo de acumulação por despossessão, em que há a privatização de um bem comum; e que esse processo somente se realiza a partir da apropriação de terras, entendida como um processo de green grabbing.

Palavras-chave: Energia eólica; interior semiárido brasileiro; acumulação por despossessão e green grabbing.

Como citar: TRALDI, M. Acumulação por despossessão e green grabbing: parques eólicos, arrendamento e apropriação de terras no semiárido brasileiro. Ambiente $\&$ Sociedade. São Paulo, v. 24, p. 1-22, 2021. 


\title{
Acumulación por desposesión y acaparamiento verde: parques eólicos, arrendamiento y acaparamiento de tierras en el semiárido brasileño
}

\author{
Mariana Traldi
}

São Paulo. Vol. 24, 2021

Tema en Destaque: Insurgencias Decoloniales y Horizontes Emancipatórios: Contribuiciones de la Ecología Política
Resumen: La generación de energía eólica se presenta como una alternativa a los combustibles fósiles, jugando un papel importante en la lucha contra el cambio climático. En este contexto, el interior semiárido brasileño emerge como una nueva frontera para la expansión de la industria eólica dado su alto potencial. Siendo el dueño de la tierra también dueño del viento, buscamos entender cómo los procesos de apropiación del viento y de la tierra para la producción de energía eólica ocurren a la luz de los conceptos de acumulación por desposesión y acaparamiento verde. Para tanto, se analizaron catorce contratos de arrendamiento eólico. Se concluyó que: los contratos de arrendamiento son el instrumento legal que permite la apropiación del viento y de la tierra; que la apropiación del viento es un proceso de acumulación por desposesión, en que se produce la privatización de un bien común; y que este proceso solo se da a partir de la apropiación de la tierra, entendida como un proceso de acaparamiento verde.

Palabras-clave: Energía eólica; interior semiárido brasileño; acumulación por desposesión y acaparamiento verde.

Como citar: TRALDI, M. Acumulación por desposesión y acaparamiento verde: parques eólicos, arrendamiento y acaparamiento de tierras en el semiárido brasileño. Ambiente $\mathbb{\&}$ Sociedade. São Paulo, v. 24, p. 1-22, 2021.

DOI: http://dx.doi.org/10.1590/1809-4422asoc20200052r2vu2021L4TD 